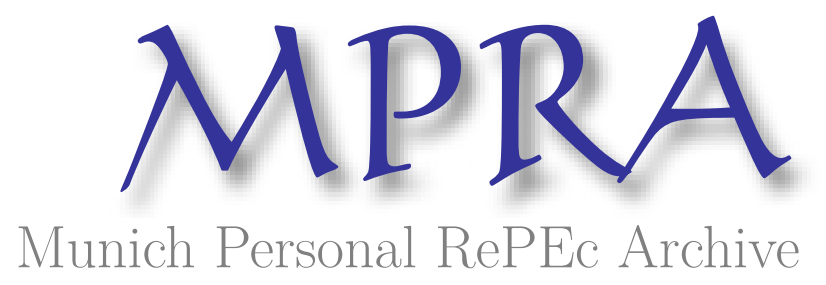

\title{
Innovation and the competitiveness of industries: comparing the mainstream and the evolutionary approaches
}

\author{
Castellacci, Fulvio
}

2008

Online at https://mpra.ub.uni-muenchen.de/27523/

MPRA Paper No. 27523, posted 20 Dec 2010 19:32 UTC 


\title{
Innovation and the Competitiveness of Industries: Comparing the Mainstream and the Evolutionary Approaches
}

\author{
Fulvio Castellacci* \\ Norwegian Institute of International Affairs (NUPI), POB 8159, Dep. 0033 Oslo, Norway
}

First submission: December 14, 2006; Final draft: August 16, 2007

\begin{abstract}
The study of the relationships between innovation and the competitiveness of industries is an important topic for both, academic research and economic policy. The huge economics literature flourished in the last couple of decades on the subject broadly falls into two distinct research traditions, namely the mainstream R\&D spillovers approach and the evolutionary economics view. Both traditions agree on the important role played by innovation and the intersectoral diffusion of advanced knowledge for the competitive performance of industrial sectors. Behind this general agreement, however, the two approaches are radically different. This paper shows that, at a deeper level of analysis, the mainstream and evolutionary views do indeed differ with respect to their theoretical foundations, empirical research and policy implications. In a nutshell, while the mainstream R\&D spillover approach is inspired by a traditional view of economic policy based on a market-oriented approach, the evolutionary view is on the contrary consistent with the idea that institutional arrangements and policy interventions do indeed play a fundamental role for shaping innovation patterns and their impacts on the competitiveness of industries.
\end{abstract}

The paper has been produced as part of the project on Innovation and Competitiveness of Nordic Services (ICONS). Financial support from the Nordic Innovation Centre and Innovation Norway is gratefully acknowledged. I wish to thank two anonymous referees of this Journal for their very helpful comments and suggestions on a previous draft of the paper.

*E-mail address: fc@nupi.no (F. Castellacci); Phone: +47-22994000 


\section{Introduction}

International competitiveness has for a long time been a relevant issue for policy and an engaging topic of academic research. It may be thought of as the ability of an industry to compete with its foreign counterparts. Behind the apparent simplicity of this definition, the concept of international competitiveness is indeed a complex one, and it is closely related to a number of different aspects $[1,2]$. The ability of an industry to compete with foreign competitors does in fact refer to its trade performance and specialization patterns, as well as to the dynamics of its productivity. These aspects are closely interwined. Productivity growth is an important factor to improve the terms of trade of an industry, and its trade performance, in turn, is a relevant engine of growth of value added and productivity.

Academic research on the subject has achieved great progress in the last two decades. Since the second half of the $1980 \mathrm{~s}$, the focus of economic research has shifted from the analysis of price- and cost-related factors of competitiveness to the important role played by technological change. The greater attention to technology and non-price factors of competitiveness corresponds to a shift of focus from short-run patterns to long-run dynamics, which has been greatly inspired by the classical contribution of Schumpeter $[3,4]$ on the role of innovation and technology diffusion in the process of growth and structural change.

Different strands of empirical research have recently flourished within the Schumpeterian tradition, providing new insights on the relationships between innovation and international competitiveness. Although the seminal contribution of Schumpeter constitutes a common source of inspiration for the recent applied work in this field, scholars belonging to different schools of thought have adopted and interpreted his theoretical view in a rather different way. 
On the one hand, a body of research within the economics mainstream has inserted some of the Schumpeterian insights within a neoclassical equilibrium framework. Socalled new growth models, in particular, have pointed to the existence of increasing returns and spillovers effects related to the $R \& D$ activities of private firms, and have thus provided the theoretical foundation for the flourishing of a huge applied literature on $R \& D$ and intersectoral spillovers $[5,6,7]$.

On the other hand, a heterogenous set of empirical studies within the evolutionary economics tradition have followed a different route, and argued that the Schumpeterian view necessarily requires a disequilibrium approach to the study of innovation, structural change and growth. Evolutionary scholars have emphasized the sector-specific nature of innovation and extensively investigated its impact on the competitiveness of different systems of innovation $[8,9,10,11]$.

These two Schumpeterian strands of research both indicate that, in a long-run perspective, the international competitiveness of industries is robustly related to two major factors, namely their own innovative activities and the intersectoral diffusion of advanced knowledge. The common focus on innovation and inter-industry diffusion has led to the widespread perception that these two schools of thought, both inspired by the Schumpeterian insights, are quite similar to each other and that, as time goes by, they are progressively becoming more and more similar and gradually converging to a common framework [12].

The present paper will critically discuss this argument and will show that, notwithstanding some important similarities, these two approaches to the study of innovation and industrial competitiveness are indeed very different from each other. In order to point out the striking differences between the mainstream R\&D spillovers approach and the evolutionary economics view, the paper will, for each of them, focus 
on three major aspects: first, the recent strands of empirical research and the main results achieved by them; secondly, the theoretical concepts and foundations underlying this empirical research; thirdly, the policy implications that can be drawn from the academic research on the subject $[13,14]$.

The discussion will show that the mainstream and evolutionary approaches greatly differ with respect to all of the three major aspects, empirical research, theoretical foundations and policy prescriptions. Future applied research in this field must more explicitly acknowledge these differences and, as far as possible, test and compare the empirical relevance of the two competing views. Technology and innovation policies must in fact be founded upon a clear, consistent and robust research framework, rather than combining policy measures suggested by two different scientific paradigms. The paper is organized as follows. Sections 2 and 3 will present the main strands of empirical research within the mainstream and evolutionary traditions respectively, and will briefly point out the conceptual framework underlying the various types of empirical studies. Section 4 will then analyse the foundations and objectives of the policy intervention in the two different approaches. Section 5 will conclude the paper and briefly discuss its implications for future research.

\section{The mainstream economics view: $R \& D$ and knowledge spillovers}

About two decades ago, the first contributions within the new growth theory tradition pointed out the important role of increasing returns for the growth process, and introduced this idea into a formal endogenous growth framework. The first models argued that investments in physical and human capital may generate externalities, increasing returns and, hence, persistent growth differences across countries $[5,15,16]$. 
Subsequently, a second generation of models focused on the role of the R\&D sector and the endogenous nature of the growth process. In the models of Romer [17] and Aghion and Howitt [6], the R\&D sector produces new blueprints for the intermediate goods sector, and the expansion of the range of intermediate goods determines increasing returns and a scale effect on aggregate growth.

The idea that sectoral $R \& D$ and $R \& D$ spillovers are important for growth and competitiveness originates therefore from these innovation-based new growth models. The main underlying assumption is that knowledge is a non-rival and (partly) nonexcludable good, and that its public good characteristics lead to the existence of spillovers, increasing returns and endogenous growth. Arguably, new growth models provide a rather stylized representation of the inter-sectoral diffusion process, which focuses on the interaction and knowledge exchange between only three macrobranches, i.e. the R\&D sector, the intermediate goods industry and the final goods sector. Notwithstanding the prevailing focus on aggregate branches and macroeconomic outcomes, new growth models do however provide an important conceptual foundation for the empirical study of the relationships between R\&D spillovers, industrial competitiveness and growth.

These theoretical models raised in fact new interesting questions for applied research. Do R\&D and knowledge spillovers effectively lead to productivity growth, and how do industries differ in this respect? Earlier empirical contributions had already explored the link between $R \& D$, inter-industry technology flows and sectoral growth ([18]; for an overview of previous works, see Nelson and Winter [8]). However, after new growth models became popular, the empirical literature investigating the impact of R\&D activities and spillovers on sectoral differences in productivity growth received increased academic attention, and it now constitutes an important field of 
applied economic research. ${ }^{1}$ Typically, these contributions consist of econometric studies where the stock of (direct and indirect) $R \& D$ is included as a production factor together with capital and labour in an extended Cobb-Douglas specification. Thus, the growth of total factor productivity (TFP) in each sector is commonly regressed on its stock of sectoral R\&D expenditures (measuring innovation) and on its indirect $R \& D$ stock (measuring R\&D spillovers from other industries).

A large part of this literature focuses on this latter aspect, namely the indirect contribution that $\mathrm{R} \& \mathrm{D}$ expenditures in a sector have on the growth of productivity in other industries, so-called R\&D spillovers [23]. From a conceptual point of view, it is possible to distinguish between two different types of spillover effects [24]. Rent spillovers are those where there is a pecuniary exchange between the provider and the recipient of technology, such as in the case of a supplier that sells an intermediate input to a user. Knowledge spillovers, on the other hand, do not entail any contractual agreement or pecuniary exchange between provider and recipient, and arise because of the public good nature of knowledge. It is therefore this second type of spillovers that more closely corresponds to the idea underlying new growth models. The major channels through which knowledge spillovers affect the growth of productivity are all related to innovating firms' $R \& D$ capabilities: reverse engineering, the mobility of R\&D employees, their participation to technical meetings and scientific conferences, and the exploitation of codified information available in the form of scientific journals and patents [25].

\footnotetext{
${ }^{1}$ There exist several overviews of this empirical literature. Nadiri [7] summarizes the main results of the major econometric works; Los and Verspagen [19] review the various methodologies used in different strands of empirical analysis; David et al. [20] focus on the relationships between private and public R\&D; finally, Bartelsman and Doms [21] and Wieser [22] review the large set of micro-level studies on R\&D and TFP growth.
} 
The conceptual distinction between rent and knowledge spillovers is important, although it is frequently not possible to separate the two categories in empirical analyses. The strategy followed by most contributions in this field is to weight the stock of R\&D of other sectors and to use it as a measure of intersectoral R\&D spillovers. This is typically done in two ways. The first is to use transaction-based weights, such as inter-industry sales or investment flows, while the second is to construct measures of technological distance between industries. The former method closely corresponds to the concept of rent spillovers, whereas the latter implicitly focuses on knowledge spillovers.

The latter way to build up a measure of R\&D spillovers has been followed by Jaffe [26], who used as weights the distribution of patents across patent classes, and by Verspagen [27,28], who used patent classifications and patent citations. These contributions, as well as several others in this field, have generally found evidence of a positive influence of $R \& D$ spillovers on sectoral productivity growth. Using a different methodology, based on a growth accounting type of sectoral decomposition of TFP, ten Raa and Wolff [29] found a similar result, and showed the importance of technological spillovers from high-tech sectors (e.g. computers and electronics) for the growth of TFP of the whole economy.

A second strand of research in the R\&D spillovers literature has extended the analysis to the investigation of the nature, extent and impacts of international knowledge spillovers. This empirical research is inspired by a class of new growth models where sectoral R\&D activities do not only sustain the dynamics of the domestic economy, but do also have positive effects for the competitiveness of foreign countries. ${ }^{2}$ In the models of Riviera-Batiz and Romer [32] and Grossman and Helpman [33], in

\footnotetext{
${ }^{2}$ For an overview of this type of new growth and new trade models, see Chui et al. [30] and Darity and Davis [31].
} 
particular, the R\&D sector produces new blueprints that increase the variety of available intermediate inputs, and the latter positively affect the growth of foreign countries through cross-border trade and knowledge flows (representing channels of rent and knowledge spillovers respectively).

The major questions that these analytical models raise are therefore whether spillovers are really global, rather than national, in scope, and which the most effective channels of international diffusion are. Considering these issues, a set of recent empirical works have weighted $R \& D$ in other countries with imports, so to obtain a measure of foreign R\&D acquired through imports of goods and services (see overview by BarbaNavaretti and Tarr [34]). In particular, Coe and Helpman [35], Coe et al. [36] and Eaton and Kortum [37] found that both domestic and international R\&D spillovers have a positive effect on the growth of TFP at the aggregate level, and that the international diffusion of knowledge is a more relevant growth engine for small open economies than for large countries.

Verspagen [27] and Keller [38] performed a similar analysis at the sectoral level, and showed that both kinds of spillovers contribute to explain differences in productivity growth across industries. However, these works also pointed out that the relative importance of domestic vs. foreign R\&D spillovers depends to a great extent on the econometric framework in which the analysis is undertaken. Foreign spillovers appear relatively more important when panel data are used, but much less relevant when the sample is cross-sectional in nature [39].

This debate on the geographical scope of R\&D spillovers is also related to a third stream of applied research, which focuses more closely on the regional clustering of innovative activities, and investigates the extent to which spillovers are local, rather 
than national or international, in scope. This is the recent empirical literature on the so-called localised knowledge spillovers (LKS). ${ }^{3}$

The main theoretical idea underlying these studies originates from analytical models in the new economic geography tradition. These models share with new growth and new trade theory the main idea that increasing returns, economies of scale and imperfect competition determine trade, specialization patterns and the growth paths of different countries. However, they additionally point out that the externalities underpinning these cumulative causation patterns are based on regional and local economies of agglomeration, rather than on country-specific factors. The microeconomic foundation of these economies of agglomeration refers to the tacit nature of knowledge, which, the LKS literature argues, has indeed the characteristics of a local public good $[44,45,46,47] .^{4}$

This means that spillovers effects exist and are important for the dynamics of the system, but also that they have a limited geographical scope. Two main types of spillovers are relevant here. The first is a Marshallian type of externality, which is related to exchanges of intermediate inputs and the mobility of skilled employees among firms located in the same region. The second mechanism is commonly defined as urbanization externality, and suggests that the diffusion of knowledge is enabled and fostered by the co-location of firms in innovative clusters. Both types of externalities, corresponding by and large to rent and knowledge spillovers respectively, point to the local nature of knowledge flows and the relevance of

\footnotetext{
${ }^{3}$ Critical discussions of this strand of research have been presented by Baptista [40], Feldman [41] and Breschi and Lissoni $[42,43]$.

${ }^{4}$ Martin [48] and Martin and Sunley [49] present critical surveys of models within the new economic geography tradition.
} 
regional clustering for sustaining the international competitiveness of innovation systems.

The econometric literature investigating this idea is relatively recent and rapidly flourishing. The common empirical strategy is to use a knowledge production function [24] to estimate the relationships between $R \& D$ and innovative output, measured in terms of patents or innovation counts $[50,51,52,53,54,55]$. Other studies are not explicitly based on a production function approach, and make use of different methodologies based on the analysis of patent citations or new product announcements $[56,57,58,59,60]$.

In a nutshell, the main result from this type of econometric studies on LKS is that innovation inputs (from private $R \& D$ or University research) lead to a greater innovation output when they originate from local sources, i.e. from firms or public institutes that are located in the same region. This stylised fact is usually interpreted as evidence of the existence of knowledge spillovers (urbanization externalities), although this may also indicate that rent spillovers (Marshallian externalities) are at work [42].

These empirical insights on the local nature of spillover mechanisms are interesting, although they appear to be in sharp contrast with the emphasis on the international scope of spillovers that other econometric studies suggest. On the whole, it seems fair to argue that the applied literature on the geographical scope of different channels of knowledge diffusion is far from having achieved conclusive results, and presents interesting challenges for future research.

In particular, this literature raises one major question. Given that $R \& D$ activities constitute a major factor to sustain the international competitiveness of industries, what does, in turn, determine sectoral differences in R\&D intensity? A large number 
of studies in industrial organization and, more recently, in the economics of innovation have in fact pointed out that $\mathrm{R} \& \mathrm{D}$ activities differ markedly across sectors, and that these differences may be explained as the outcome of the interplay of a complex set of sector-specific characteristics [25]. Hence, the competitiveness of domestic sectors in foreign markets does not merely depend on their R\&D intensity but, first and foremost, on the structural characteristics that define the industryspecific opportunities, strategies and obstacles of innovative activities in different sectors. For instance, it has been shown that some low-tech and traditional industries do not innovate by undertaking formal R\&D activities, but rather by acquiring advanced capital equipments from other sectors [61]. In this case, the econometric strategy based on the estimation of R\&D spillovers is likely to underestimate the innovative activities carried out by these sectors.

A different research tradition, rooted in evolutionary economics, emphasises the sectoral specificities of the innovative process, and it approaches the study of the international competitiveness of industries in a rather different way. To the discussion of this evolutionary literature we now turn.

\section{The evolutionary view: technology-gaps, vertical linkages and innovation systems}

The general proposition that innovation and intersectoral knowledge spillovers are important for the international competitiveness of manufacturing industries is a major point of agreement between new growth theories and evolutionary economics. The two approaches, however, differ substantially in terms of the conceptualization of the innovative process and the analysis of its economic impacts. 
Evolutionary economics conceives innovation as a paradigm-bounded, sector-specific and context-dependent activity. The paradigmatic nature refers to the existence of dominant technological paradigms that create, in any given historical era, a set of opportunities and constraints for innovative activities [62,63,9].

Industries, however, "differ significantly in the extent to which they can exploit the prevailing general natural trajectories, and these differences influence the rise and fall of different industries and technologies" [8, p. 59]. Thus, the paradigmatic nature of technological knowledge does not only explain the relatively ordered patterns that may be observed in each phase of long run growth at the aggregate level [10], but also the inherent tendency towards qualitative change and transformations at the sectoral level. This accounts for the industry-specific nature of innovation, which naturally leads, in turn, to give emphasis to the systemic context in which the innovative process unfolds. In the evolutionary view, the impact of innovation on the international competitiveness of industries must therefore be analysed within a complex framework comprising both, the broader systemic context shaping innovative activities, and the sectoral specificities that characterize the creation and diffusion of knowledge.

In the last two decades, a large body of empirical research has developed within this tradition, and has extensively investigated the role of innovation for international competitiveness. This empirical literature is rich, and it has achieved considerable results. However, the different strands of research within evolutionary economics have not yet agreed on a standard set of models, methodology and stylized facts. This makes the task of summarizing this heterogenous literature rather complex.

Figure 1 presents an attempt to organize this vast body of empirical research. The diagram reported in the figure represents the major strands of evolutionary applied 
research that have investigated the relationships between sectoral innovation and international competitiveness. Each arrow in the diagram corresponds to a branch of applied literature, and the variables on which this focuses. On the whole, figure 1 may therefore be considered as a stylized representation of a general evolutionary model, yet to be written, which is based on the co-evolution and the dynamic interactions between the systemic context, the creation of knowledge within sectors, the vertical linkages among industries, and their international competitiveness. This section clarifies the different parts of this evolutionary model by referring to the major strands of research and the main empirical results achieved by them. The evolutionary approach points out that the impact of innovation on international competitiveness depends on five major factors.

\section{$<$ Figure 1 here >}

\subsection{Sectoral innovative activity}

The technology-gap hypothesis argues that innovation is a major determinant of the competitiveness of industries in international markets. This idea was originally inspired by the seminal contribution of Posner [64], and was subsequently investigated by a large number of empirical studies. These econometric works typically take the form of cross-section analyses of the relationship between measures of input and/or output of innovative activities (i.e. R\&D and patents, respectively) and the trade performance of different industries. This set of studies has pointed out that sectoral innovative activity is indeed a major determinant of international competitiveness, and that therefore, in a long run perspective, non-price factors are 
significantly more important than price related variables $[65,66,67,68,69,70,71,28,72,73,74,75]$.

A related strand of research within the technology-gap tradition focuses on the impacts of innovative activity on the dynamics of labour productivity at the macroeconomic level. Macro-oriented studies of this type have shown that crosscountry differences in productivity and GDP per capita levels can be explained, among several other factors, by countries' abilities to innovate as well as their capability to exploit the international diffusion of technologies, so-called absorptive capacity $[76,77,78]$. These studies suggest that imitation, far from being an automatic and easy activity, is a costly process that requires an active effort to build up a strong social capability and an advanced industrial structure $[79,80,81]$.

This finding points out that sectoral innovative activity does not only have a direct positive effect on international competitiveness through its impact on trade performance, but an indirect effect as well, given that the upgrading of a country's industrial structure increases its absorptive capacity and, hence, its ability to imitate foreign advanced technologies $[82,83]$. The two aspects, sectoral innovative activity and international diffusion of new technologies, are therefore closely related to each other, and both of them are important to sustain the competitiveness of national industries in the international arena.

\subsection{Vertical linkages and intersectoral knowledge flows}

A related strand of research within the evolutionary tradition investigates the so-called home market hypothesis. This was originally put forward by Porter [84] and Lundvall [85]. The idea is that the home market constitutes a fundamental arena to develop, test and commercialise new products in the early phase of their introduction, before they 
are eventually exploited in foreign markets. The characteristics of the home market, and particularly the vertical linkages between suppliers, producers and users of advanced technologies, represent therefore a major factor of competitive advantage. The focus on the importance of vertical linkages is intrinsically related to the sectorspecific nature of innovation. A large set of evolutionary studies has in fact shown that innovative activities, strategies and performance greatly differ among manufacturing industries, and that different sectors tend to follow very distinct technological trajectories over time [8,86]. Pavitt [87], in particular, put forward a well-known taxonomy that identifies four sectoral trajectories, i.e. four groups of industries characterized by markedly different innovative modes, namely sciencebased, scale intensive, specialised suppliers and supplier dominated industries. The most original feature of Pavitt's taxonomy is its focus on the intersectoral exchange of advanced knowledge that continuously flows among the various industry groups, so that each of them assumes a well-distinct and specific function in the system of innovation as a provider and/or recipient of technology to/from the other groups of sectors.

Inspired by these insights on the importance of the home market and its vertical linkages, a recent strand of empirical research has investigated their relevance to explain the international competitiveness of different industries. ${ }^{5}$ These econometric studies have considered, in addition to variables typical of the technology-gap approach, the role of intersectoral knowledge flows to explain the dynamics of export market shares and specialization patterns, and have shown, in particular, the importance of user-producer interactions and of upstream linkages between suppliers

\footnotetext{
${ }^{5}$ This recent empirical research has also been fostered by the greater availability and diffusion of data from the Community Innovation Survey (CIS), which is a large-scale survey that is undertaken biannually in all European countries. CIS data make it possible to measure a rich set of characteristics of innovative firms and their vertical linkages, and explore the impacts of these on growth and competitiveness in different industries $[61,88,89,90]$.
} 
and producers $[91,92,93]$. Furthermore, using Pavitt's taxonomy as a framework, the home market hypothesis literature has shown that vertical linkages are not equally supportive of foreign competitiveness for all different groups of manufacturing industries. Upstream linkages, in fact, are more important factors for scale intensive sectors, downstream linkages are more relevant to shape the competitive position of specialised suppliers, whereas University-industry links constitute a more crucial factor for science-based industries [94,95,13].

\subsection{Technological regimes}

The strands of evolutionary applied literature presented above raise one major question. Given that sectoral innovative activity and intersectoral knowledge flows are important factors to sustain the international competitiveness of manufacturing industries, what does in turn determine them? In the investigation of the sectorspecific characteristics of the innovative process, the focus of evolutionary studies is on the nature of learning processes, which are specific to a given technological environment. A technological regime $[62,96]$ defines such a technological environment, i.e. the framework conditions in which firms' innovative activities take place. In each sector of the economy, some technological characteristics affect the direction and intensity of learning processes and the knowledge accumulation by economic agents.

Extending previous empirical works in industrial organization [97], recent evolutionary studies have focused on four main characteristics of sectoral technological regimes: (i) the nature of the knowledge base, i.e. the "properties of the knowledge upon which firms' innovative activities are based" [98, p.136]; (ii) the appropriability conditions, i.e. the possibilities of appropriating the innovative rents 
by protecting innovations from imitation through a variety of means, such as patents, process secrecy and know-how, design and R\&D know-how, and other non-technical means; (iii) the cumulativeness conditions, which define the extent to which current innovative activity builds upon the experience and results obtained in the past; (iv) the technological opportunities, i.e. the "likelihood of innovating for any given amount of money invested in search" [86]. This definition focuses on the level of technological opportunities, that is on the relationships between input and output of the innovative process in different sectors of the economy. However, besides the level of opportunity, there are other important aspects that contribute to shape sectoral technological opportunities, such as its variety, pervasiveness and sources. The exploitation of technological opportunities is thus a complex and multifaceted process, and it is strictly linked to the existence of major dominant technological trajectories in different industries of the economy $[99,88]$.

The investigation of the nature of technological regimes has recently led to a surge of applied research in evolutionary economics. In particular, it has been shown that the characteristics of technological regimes may shed new light on two relevant aspects of the innovative process.

First, they may explain the existence of different patterns of market structure and industrial dynamics in different sectors of the economy. Most of the recent works in this field $[100,101,98,102]$ have focused on sectoral differences in terms of concentration of innovative activity, size of innovative firms, ease of entry in the market, turbulence or stability in the population of innovative firms. These studies have argued that sector-specific technological regimes may explain the existence of the two main patterns of innovation originally pointed out by Schumpeter $[3,103]$. The first, the Schumpeter Mark I, is characterized by high ease of entry in the market, 
low concentration of innovative activity, and a turbulent population of new and old innovators with a significant role played by small firms. Creative destruction [3] is the main feature of this regime (also defined 'entrepreneurial' or 'widening'). The second, the Schumpeter Mark II pattern, is characterized by high barriers to entry for new innovators, high concentration of innovative activity, and a stable population mainly formed by large and well-established firms. Creative accumulation [103] is the distinctive feature of such a regime, also defined 'routinized' or 'deepening'. Secondly, a more recent branch of research has focused on the impact that sectoral technological regimes have on the international competitiveness of industries. Malerba and Orsenigo [100,101] and Malerba and Montobbio [104] show that technological opportunities, properties of the knowledge base, appropriability and cumulativeness conditions are relevant factors to explain the patters of international technological performance, measured by the 'revealed technological advantage' in terms of patents. Relatedly, the characteristics of technological regimes have also been shown to have an impact in terms of export market share dynamics. Based on the estimation of a technology-gap trade model, other econometric studies have in fact found that sectoral trade performance is closely related to a range of industry-specific technological variables, such as technological opportunities [105], cumulativeness [106] and appropriability conditions [89]. In a nutshell, these studies provide an extension and a refinement of the technology-gap approach, as they shed new light on the links between the structural characteristics of sectoral systems of innovation, on the one hand, and their competitiveness in international markets, on the other. 


\subsection{The co-evolution of national and sectoral systems}

Evolutionary economics emphasizes the context-specific nature of innovative activities. In the study of sectoral patterns and impacts of innovation, the context that it is relevant to look at does not simply refer to the structural characteristics defining the industry-specific technological regime, but also the broader systemic context within which the innovative process unfolds [107]. Sectoral innovation is greatly shaped by the characteristics of the national system of innovation, and the latter, in turn, is affected by the former. The co-evolution of national and sectoral systems is therefore a major factor to drive international competitiveness.

The idea that sectoral and national systems are interwined has been recently put forward by Mowery and Nelson [108], Murmann and Homburg [109], Malerba [86] and Castellacci [13]. These studies have pointed out the existence of three channels of interactions between sectoral patterns and national systems.

The first refers to the performance of national systems. The technology-gap and home market hypotheses discussed above point out that sectoral innovative activities and intersectoral knowledge flows contribute to shape the specialization patterns, productivity dynamics and trade performance of the whole system of innovation. Several empirical studies, in addition, indicate that the specialization profile matters for macroeconomic performance, and that countries that are able to shift their industrial structure towards areas characterized by higher technological opportunities experience a more dynamic aggregate performance in the long run $[110,111,112,113,114,115,116]$.

In turn, the country-specific patterns of scientific, technological and economic specialisation, together with the other features characterizing the home market, affect, strengthen and reproduce over time the innovative activities of the domestic producers 
and the intersectoral linkages between producers, suppliers, users and the science system $[84,85,108]$. Various empirical studies have in fact shown the continuity and persistence of country- and sector-specific technological trajectories and specialisation patterns over long periods of time $[117,118,119,120,121,122,123]$. Secondly, the policy level constitutes a major channel of interaction between the meso and the macro level. In fact, the existence of important industries or core industrial areas where the country is specialised, with the related set of well-established vertical linkages that they entail, may shape regulations and governmental decisions at the national level, and affect in particular (i) innovation policies, (ii) industrial policies, (iii) IPRs regulations, and (iv) University-industry links [108]. If national policies actively promote core industrial areas for a prolonged period of time, and neglect others, this policy strategy will affect the entire national system of innovation, which may eventually turn out to be locked in into a specific path [124]. Conversely, national policies may directly affect sectoral innovative activities, cooperation patterns, intersectoral linkages and University-industry collaborations through a wide variety of incentives, schemes and regulations $[125,126]$.

Thirdly, a broad range of other country-specific factors, of a social, institutional, and cultural nature, affect, as well as are shaped by, the degree of trust and cooperation in the system and, relatedly, the intensity of intersectoral linkages and the exchange of advanced knowledge. Network interactions and systemic relationships are in fact embedded in, and co-evolve with, a complex set of social and cultural factors that are specific to a given national framework [127].

In short, the co-evolution between sectoral patterns and national systems of innovation tends to strengthen and reproduce a given country- and industry-specific technological trajectory over time. Sectoral innovative activities and vertical linkages, 
due to their persistent, enduring and context-dependent nature, are fundamental for explaining the cumulative and path-dependent dynamics that innovation systems follow over time and their patterns of international competitiveness.

\subsection{The co-evolution of regional and sectoral systems}

In addition to the national system of innovation, a relevant context that shapes sectoral innovative activities and performance is the regional one. Regional systems co-evolve with sectoral patterns of innovation, and the competitiveness of industries in the international arena must therefore be sustained by the dynamic interaction between regional and sectoral systems. This argument comprises two distinct causal mechanisms, each of which refers to a different branch of empirical research. The first is the so-called geography of innovation and economic clustering [128]. This is a recent body of literature within evolutionary economics, which emphasizes the relevance of clustering of innovative activities in space and investigates the factors that may explain these spatial patterns. The evidence that innovation clusters in successful regions, rather than spreading uniformly across the geographic space, is robust. This empirical evidence has been provided by different strands of research, ranging from the localised knowledge spillovers literature (see section 2), to the studies of industrial districts and regional success stories [84], to the analysis of the internationalization of MNEs' R\&D activities, or lack of such [129]. A recent generalization of these previous bodies of research is constituted by the regional systems of innovation approach, which argues that innovation is a systemic process that is inherently shaped by the characteristics of the regions where innovative activities are located $[130,131,132]$. In a recent overview of this literature, Asheim and Gertler [133] point to three main factors that determine the clustering of 
innovative activies. The first is the tacitness of the knowledge base, which refers to the localised and embedded nature of learning and innovation, and which implies that learning through interacting mechanisms and vertical linkages frequently require the geographical proximity of suppliers, producers and users of new technologies. The second refers to the existence of public sources of technological opportunities, which means that the availability of public facilities and infrastructures (e.g. R\&D labs, Universities, technical schools) provides a strong incentive for innovators to locate in advanced regions. The third is a mechanism of regional cumulativeness, i.e. the fact that successful regions are better able to attract advanced resources (skilled labour, specialised suppliers, engineers, etc.) that will ensure further technological and economic success in the future.

These three factors, though, do not affect all manufacturing industries in the same manner [134]. The availability of public sources of technological opportunities and close University-industry links is in fact a more relevant factor to shape the location choice of firms in science-based sectors, while specialised suppliers and scale intensive firms require geographical proximity because of the highly tacit nature of the knowledge base that they use in their interaction process. In more general terms, clustering is a more relevant factor of competitiveness for industries characterized by high levels of technological opportunities, high appropriability and cumulativeness conditions, and a complex and tacit knowledge base [98]. In other words, clustering is a particularly important aspect for technologically advanced industries, which are precisely those that constitute the major engine of growth and the most competitive branch of the system of innovation.

While the literature on the geography of innovation and economic clustering establishes a causal mechanism where regional characteristics affect the patterns and 
performance of innovative activities, a related branch of empirical research focuses on the opposite mechanism, namely the effect that innovation has on the economic performance and the evolution of regional systems. Various econometric studies have investigated the patterns of convergence across European regions, focusing on the role that innovation has to explain cross-regional differences in the dynamics of productivity and GDP per capita $[135,136,137,138,139]$.

These studies are rooted in the technology-gap tradition presented above, and they typically take the form of cross-section estimations where regional growth is regressed on the initial level of GDP per capita, measuring the scope for diffusion, some indicators of innovative activity (e.g. patents or R\&D), and a set of control variables, such as the industrial structure of the region, which measure the absorptive capacity and the ability of each region to exploit the international diffusion of technologies. The empirical evidence robustly shows that EU regions are not on a converging path and that, particularly in the last decade, advanced regions have been significantly more dynamic than backward regions. Technology-gap econometric studies indicate that innovation is indeed a relevant factor to explain this pattern of regional divergence, and that poorer regions have frequently not been able to exploit the opportunities provided by the international diffusion of ICT-related technologies [119].

Thus, the impact of innovation on the dynamics of regional systems varies significantly across EU regions, so that we observe the existence of different regional convergence clubs, rather than the uniform pattern of $\beta$-convergence that neoclassical economic theory would predict. The dynamics of these convergence clubs is closely related to the industrial structure and the specialization patterns of different regions, given that regions specialized in technologically advanced sectors tend to converge 
towards a more rapid growth path than regions specialized in traditional and low-tech productive activities [140,141,142].

Taken together, the two strands of research discussed in this section indicate that the co-evolution of sectoral and regional systems is a major factor of international competitiveness. Sectoral innovative activities and vertical linkages are greatly shaped by the characteristics of regional systems and the latter, in turn, are strengthened, reproduced and transformed over time by sectoral patterns of innovation. This coevolution suggests the existence of cumulative causation patterns, where high-tech industries more frequently cluster in successful regions, thus contributing to make them even more successful in the future. This is a major factor of international competitiveness as well as a source of increasing regional disparities.

\section{Policy foundations and objectives: comparing the two approaches}

In both economic approaches reviewed in the previous sections, mainstream and evolutionary, the key factors to explain the long-run competitiveness of industrial sectors are their own innovative activity and their ability to exploit the intersectoral diffusion of advanced knowledge. However, behind this broad agreement on the central role played by innovation and diffusion in the growth process, the two approaches greatly differ in terms of their empirical research style and basic theoretical structure. The foundations and the objectives of policy-making are, as a consequence, radically different in the two theoretical paradigms. This section discusses the policy implications of the mainstream and evolutionary views, and points out the great differences existing among them. Table 1 summarizes the main points of the discussion carried out in this section. 


\subsection{Policies in the mainstream $R \& D$ spillovers approach}

In the mainstream view, the key aspect of the innovative process is the R\&D activity undertaken by private firms. $R \& D$ expenditures are regarded as the major input in the knowledge creation process, which leads to the technological output (new products and processes) and spurs the economic performance of the innovative firm. This input-output link is rooted in a linear understanding of the innovative process, and commonly applied in empirical studies by means of a production function approach. The focus of policy-making is thus, first and foremost, the level of R\&D expenditures of private firms, and the rationale is to create an appropriate system of incentives and resources to stimulate the production of new technological knowledge by economic agents.

But the level of R\&D activity undertaken by private firms is, in general terms, suboptimal, due to the public-good nature of knowledge. This in fact leads to spillovers and increasing returns in the growth process, thus making the actual level of $R \& D$ expenditures lower than what would be optimal from a social welfare point of view. Baumol $[143,144]$, however, points out that the Pareto optimal level of R\&D expenditures is not the one corresponding to a zero-spillovers situation. $\mathrm{He}$ emphasizes the existence of a trade-off between the disincentive to innovative activities that are caused by knowledge spillovers and the beneficial effects that the latter lead to for non-innovators. Thus, the Pareto optimal level of R\&D falls within a range, so-called spillovers ratio, where knowledge spillovers are positive and maximize social welfare.

The need to sustain private $R \& D$ activities while at the same time maximing social welfare constitutes therefore the basic foundation for R\&D support policies. These 
make it possible, in the neoclassical metaphor, to correct the market failure and return to a state of Pareto optimality. R\&D policies are thus considered as an application of the traditional market-failure approach to the market of knowledge $[145,146]$. This extension is naturally rooted in an equilibrium context, which is the necessary foundation of the principle of Pareto optimality, as well as in the existence of a rational social planner that optimizes collective welfare by allocating resources to economic agents. The social planner is implicitly assumed to have perfect information regarding the actual and desired states of the world, and to be able to foresee with certainty the consequence of any given policy measure. The social planner metaphor is founded upon an economic environment characterized by computable risk [147], and no radical uncertainty arises in this context.

The economic environment is indeed conceived as a smooth platform upon which economic agents carry out their business and innovative activities, but it does not really constitute a structure shaping and constraining their behaviour. The microeconomic foundation represents the key aspect of the theory, and the aggregate (sectoral and macroeconomic) properties of the system can simply be derived from the description of the behaviour of microeconomic agents (methodological individualism). The important implication of this is that there is no feedback mechanism from the macro to the microeconomic element, from the structure to the agent, and that therefore the economic and socio-institutional context in which policy measures are undertaken does not play a fundamental role in shaping the effectiveness of the policy intervention. In other words, the policy implications that can be derived from R\&D spillovers models provide a set of general rules that can be applied regardless of the specificities of the economic and socio-institutional context in which the policy-maker operates. The emphasis in the mainstream theory building is on the 
construction of relatively simple analytical models, and this naturally leads to onesize-fits-all implications and generic policies.

Given this conception of the foundations of policy interventions, what are, more specifically, the policy objectives that must be achieved in order to sustain innovative activities and the international competitiveness of industrial sectors? The strands of mainstream research considered in section 2 lead to highlight three main policy objectives. The first and most important pillar is the need to increase the size of the R\&D sector in order to correct the market failure arising due to the existence of $R \& D$ spillovers-related externalities. The R\&D policy to support the innovative activities of the domestic R\&D sector is assumed to have a twofold positive effect: on the one hand, it enhances the productivity and performance of the sector, thus sustaining its competitiveness in international markets; on the other, it increases the intersectoral diffusion of knowledge towards other industries (i.e. those producing intermediate and final products), so enhancing the competitiveness of the whole industrial system. The instruments through which the R\&D support policy is carried out typically include R\&D subsidies and tax deductions, and schemes to strengthen IPRs and the appropriability of the results of innovative activities (e.g. patents).

The second objective refers to the international level, and it arises from the analytical models and applied studies in the international spillovers research strand. These studies emphasise the importance of international trade and implicitly suggest that the free exchange of goods and services in the world economy has a twofold beneficial effect on the competitiveness of industries: first, it enables the international flow of technological knowledge among industries; secondly, it spurs the productivity of domestic producers by making them compete with foreign firms in the international arena. In a nutshell, trade specialization and comparative advantages are in this view 
the key aspects that policy-makers must look at in order to sustain the international competitiveness of domestic sectors.

The third policy objective relates to the regional level, and it is founded upon models and empirical studies in the new economic geography tradition. This emphasises the existence of local knowledge spillovers and the relevance of these to sustain the performance of successful regions. In this framework, policies should indeed support the innovativeness and competitiveness of advanced regions and, by doing so, they will strengthen the regional specialization patterns and thus benefit the whole economic system. The drawback of this policy emphasis on successful geographical clusters is that backward regions will in general not be able to catch up, so that within-country regional disparities are likely to increase. In this approach, the tradeoff between these different policy objectives, the strengthening of regional specialization patterns versus the achievement of cohesion and cross-regional equality, is arguably in favour of the former.

\subsection{Policies in the evolutionary framework}

Private $R \& D$ activities are of course considered an important element of the innovative process also in the evolutionary framework, although they are by no means the only aspect that it is relevant to look at in order to support the competitiveness of industrial systems. Innovative firms follow well-distinct strategies in different sectors of the economy, and it has been shown, in particular, that the innovative process in traditional and low-tech sectors is based on a variety of different strategies, such as the acquisition of capital equipments and machineries that embody advanced technologies, rather than on formalized R\&D activities [87]. 
The sector-specific nature of the process of technological change and the existence of significant inter-sectoral differences in the pace and type of innovative activities give emphasis to the important role played by learning and competence building in the economic system. Policies sustaining the human capital formation are not only crucial in the R\&D intensive branches of the economy, but in more traditional sectors as well, where they have the purpose to upgrade the absorptive capacity of less advanced industries and foster the process of inter-sectoral diffusion of new technologies. Innovation policies must take the sector-specific nature of technological change as a fundamental starting point, and target the appropriate set of innovative strategies and constraints that are crucial for the competitive success of different sectoral systems. Thus, instead of a generic policy of R\&D support based on an incentives-andresources rationale, innovation policies in an evolutionary framework must encompass a broader set of interventions to foster and upgrade the technological and learning capabilities of the various components of an innovation system $[148,146]$. The components of a system of innovation do not only include private firms and their R\&D activities, but also public organizations such as Universities, public research institutes, science parks and so on. The latter may in fact play a pivotal role in an innovation system, given that they represent the knowledge infrastructure of the economy and play an important twofold function. On the one hand, they sustain the formation of human capital and learning capabilities of all economic agents; on the other, they enable the accumulation and diffusion of advanced knowledge in the innovation system. The R\&D activities undertaken by private firms greatly benefit from the existence of a well-functioning set of public organizations in the S\&T domain, and these institutions should therefore be actively supported by public policies. 
However, the various components of an innovation system, both private and public, would have no relevance without a well-developed network of relationships linking them together. The other key rationale of policies in an evolutionary framework is therefore to support and foster the connections and interactions among the various components of the system, which constitute the basic structure defining the properties of a system and its dynamic trajectory over time [149]. According to the evolutionary metaphor, the growth of an innovation system follows a complex dynamics that cannot be analysed within an equilibrium framework. It is a never-ending process of transformation driven by the interaction of a complex set of factors of an economic, institutional and historical nature. In this context, evolutionary theories argue, the mainstream metaphor of Pareto optimality and market failure corrections cannot be applied [125].

In the evolutionary theoretical framework, policies are indeed necessary to shape the patterns and outcomes of innovative activities, and their rationale is to target system failures. These policies' purpose and effect will not be to set back the system towards an equilibrium balanced path, but rather to enhance social welfare in an environment characterized by continuous and disruptive change and radical uncertainty [147].

Given the purpose to enhance social welfare, the evolutionary approach recognizes the existence of the trade-off pointed out by Baumol $[143,144]$ between the disincentive to innovative activities that are caused by knowledge spillovers and the beneficial effects that the latter lead to for non-innovators. In this theoretical framework, however, the emphasis is given to the positive effects of spillovers for social welfare rather than the need to strengthen appropriability regimes to protect innovators [25]. The distributive effects of knowledge externalities are considered far 
more relevant for enhancing social welfare than the loss of efficiency due to the possible disincentive for innovators to engage in $R \& D$ activities in the future [150]. The policy-maker in this evolutionary context is much like all other economic agents, a bounded-rational agent with limited information about the precise links between a current and a future state of the world. The policy-maker's capability of shaping the direction of an innovation system in such a complex and uncertain environment constitutes a crucial factor of competitiveness, and it is itself one important target of the innovation policy process.

Differently from the mainstream view based on the principle of methodological individualism, in the evolutionary framework the structure upon which innovative activities unfold does indeed shape the strategies and outcomes of economic agents. The co-evolution between the micro and the aggregate level of analysis in innovation system research (non-reductionism) explains the fundamental role played by the context, that is the sector-specific, institution-dependent and time-contingent economic environment in which economic agents' innovative activities are carried out. In a theoretical world where the context plays such a seminal role, policies must necessarily be targeted to the specific characteristics and need of different sectoral, regional and national systems.

Let us now point out more explicitly the implications of these general evolutionary policy foundations in terms of the specific objectives of innovation policy. In order to foster innovative activities and enhance their impact on the international competitiveness of industries, evolutionary theories suggest to structure the policy intervention around three major areas.

The first objective is of course to increase sectoral innovative activities, which are supposed to have a twofold positive effect: on the one hand, they support the trade 
performance of the innovative industry, and on the other they enhance its technological capability and absorptive capacity, thus enabling the process of imitation of foreign advanced technologies. In an evolutionary framework, though, the public support to R\&D activities is only one aspect of innovation policy, and the latter must in more general terms sustain the sector-specific structure upon which innovation is founded in different industries of the economy. In other words, innovation policy must target the sector-specific opportunities, cumulativeness and appropriability conditions, which are the structural characteristics defining the technological regime of each sectoral system.

The importance of technological opportunities implies that public policies must undertake an active effort to transform the industrial structure towards sectors characterized by high and emerging opportunities, because these are the most dynamic industries that are able to drive the competitiveness of the whole national system of innovation. The focus is thus on the need to build up new competitive advantages in the most dynamic industrial areas, rather than to strengthen existing comparative advantages and specialization patterns inherited from the past. However, while the building up of new competitive advantages is a strategy that requires the investment of a considerable amount of resources over a long period of time, a more feasible objective in the shorter term would be to enhance the learning capability and absorptive capacity of less advanced sectors as well, so to enable and accelerate the process of inter-sectoral diffusion of advanced technologies. Policies aimed at competence building in more traditional industries may in fact contribute to lengthen their mature life cycle and recreate new technological opportunities in the less technologically advanced branches of the economy [151]. 
The relevance of cumulativeness conditions calls the attention to the evolutionary trade-off between variety and selection. In fact, in the early phase of diffusion of a new emerging technology, policies must try to increase the variety in the market by encouraging the entry of new innovators, in order to avoid a situation of early lock-in and path-dependency. But in a later phase of the industry life-cycle, say in more traditional and mature sectors, policies should instead ensure the existence of a wellfunctioning selection process favouring the efficiency of innovative outcomes [152]. It is therefore important that innovation policies implement a set of measures that are appropriate to the stage of industrial development of any given industry; the same policy can in fact lead to opposite outcomes when applied to two different phases of the industry life-cycle.

As regards the sector-specific appropriability conditions, evolutionary theories point out the existence of a trade-off between an incentive and an efficiency effect. While the former suggests to strengthen IPRs and other means of appropriability of innovative firms, the latter indicates that the intersectoral diffusion of knowledge and the related spillover effects may be more crucial factors for the competitiveness of a national system in the long run $[25,150] .^{6}$

Besides, when the objective of policies is to strengthen appropriability conditions, this should be achieved by targeting the specific means of appropriation that innovative firms adopt in different sectors of the economy, rather than implementing a generic policy that focuses on formal and traditional means of appropriation (e.g. patents) for all industrial sectors (as it is typically prescribed by the mainstream view).

\footnotetext{
${ }^{6}$ This is also in line, as previously noted, with Baumol's analysis of the Pareto optimal size of spillovers [143,144]. While sharing a similar emphasis on the importance of spillover effects for social welfare, Baumol's view does however differ from the evolutionary in that his analytical results are obtained in an equilibrium and Pareto optimality type of analytical framework.
} 
While this first set of policy objectives may be thought of as focusing on the individual components of an innovation system, the second area refers to the set of policies aimed at strengthening the relationships and interactions among the components of the system [153]. Here, the purpose is to support and develop vertical linkages among sectors, which constitute the fundamental structure favouring the exchange of advanced knowledge and sustaining the international competitiveness of a national system. In those clusters of vertically-integrated industries where the country is specialized, the interactions between producers, suppliers and users of new technologies should of course be strengthened. In those sectors where the economy has not a traditional stronghold, however, vertical linkages should be actively supported through cooperation schemes and, particularly in the case of small open economies, through incentives to build up these linkages by cooperating with foreign advanced firms. In a nutshell, the emphasis here is on the need to develop an advanced domestic industrial structure, rather than to focus on the country's specialization patterns.

The third set of policy objectives relates to the context-dependent nature of innovation and industrial competitiveness $[154,14]$. The co-evolution between national and sectoral systems implies that public policies must take into account the interactions existing between different institutional levels, and thus coordinate as much as possible sector-specific innovation and industrial policies with nation-level policies governing the macroeconomic environment, the trade and financial regimes, and the education system. Similarly, the need for a closer coordination of different policy levels emerges when we focus the attention on the co-evolution between sectoral and regional systems. Regional factors constitute a key aspect for the competitiveness of sectoral systems, and regional policies do therefore play a relevant role in the innovative 
process. In particular, science-based industries require public investments to provide advanced sources of scientific opportunities (e.g. Universities and public research institutes), while specialised suppliers and scale-intensive sectors are greatly supported by public policies for the upgrading of the regional infrastructures, which favour their co-location and knowledge exchange in advanced regions.

The scope of regional policies must however not be limited to competitivenessenhancing interventions in advanced industrial clusters. In the knowledge-based economy, less favoured regions increasingly run the risk of falling behind, and cohesion policies constitute therefore an important complement to competitiveness measures. Regional cohesion policies, rather than simply redistributing resources from advanced to backward regions, should aim at actively fostering the technological capability and absorptive capacity of the latter [139]. Competitiveness and cohesion should thus be regarded as two complementary policy objectives.

\section{< Table 1 here >}

\section{Conclusion}

The paper has carried out a critical survey of the most influential contemporary economic approaches to the study of innovation and the international competitiveness of industries, namely the mainstream R\&D spillovers literature and the evolutionary economics view. For each approach, the discussion has presented the main recent strands of empirical research, the major theoretical foundations upon which they are based, and the policy implications that can be drawn from them. 
The main conclusion of the paper is that these two approaches greatly differ in terms of all aspects, empirical research, theoretical views and policy implications. Thus, contrary to what frequently asserted, these two Schumpeterian strands of research are rooted in well-distinct theoretical worlds and provide very different foundations for policy interventions in the area of innovation and industrial competitiveness.

What is the implication of this result for the research agenda in this field? Empirical research on innovation and industrial competiveness must more clearly and more explicitly distinguish between the two approaches. In fact, while applied economic studies tend frequently to neglect the existence of differences in terms of theoretical interpretations and policy implications, these should be made explicit and, whenever possible, they should be compared and tested against each other.

The empirical tests of the basic assumptions and propositions underlying the two different approaches would not have a purely academic interest, but they would also be greatly relevant from a policy perspective. Technology and innovation policies must in fact be founded upon a robust theoretical and empirical framework, and it should therefore be clear to policy-makers what this robust analytical framework really is. Policy interventions that are founded upon a combination of the two different views may in fact result in problematic and perverse consequences for the economic system. Innovation research must as far as possible provide policy-makers with an unambiguous, consistent and well-founded set of guidelines for the formulation of technology and innovation policies. 


\section{References}

[1] Archibugi, D. and Michie, J.: Technical change, growth and trade: new departures in institutional economics, Journal of Economic Surveys 12 (3): 313-332 (1998).

[2] Cantwell, J., Innovation and Competitiveness, in The Oxford Handbook of Innovation. J. Fagerberg, D. C. Mowery and R. R. Nelson, eds., Oxford University Press, Oxford, 2005.

[3] Schumpeter, J.: The Theory of Economic Development, Harvard University Press, Cambridge, USA, 1934.

[4] Schumpeter, J: Business Cycles, Porcupine Press, Philadelphia, 1939.

[5] Romer, P.: Increasing returns and long-run growth, Journal of Political Economy 94: 1002-1037 (1986).

[6] Aghion, P. and Howitt, P.: A model of growth through creative destruction, Econometrica 60: 323-351 (1992).

[7] Nadiri, M. I.: Innovations and technological spillovers, NBER Working Paper No. 4423 (1993).

[8] Nelson, R. and Winter, S.: In search of a useful theory of innovation, Research Policy 6: 36-76 (1977).

[9] Freeman, C., Clark, J. and Soete, L.: Unemployment and Technical Innovation, Pinter, London, 1982.

[10] Dosi, G.: Sources, procedures, and microeconomic effects of innovation, Journal of Economic Literature XXVI: 1120-1171 (1988).

[11] Devezas, T.C.: Evolutionary theory of technological change: state-of-the-art and new approaches, Technological Forecasting and Social Change 72 (9): 1137-1152 (2005).

[12] Mulder, P., De Groot, H. L. F. and Hofkes, M. W.: Economic growth and technological change: a comparison of insights from a neoclassical and an evolutionary perspective, Technological Forecasting and Social Change 68 (2): 151$171(2001)$.

[13] Castellacci, F.: The interactions between national systems and sectoral patterns of innovation. A cross-country analysis of Pavitt's taxonomy, DIME Working Paper 2006.01 (2006).

[14] Conceição, P. and Heitor, M. V.: Diversity and integration of science and technology policies, Technological Forecasting and Social Change 74: 1-17 (2007).

[15] Lucas, R.: On the mechanics of economic development, Journal of Monetary Economics 22: 3-42 (1988). 
[16] Azariadis, C. and Drazen, A.: Threshold externalities in economic development, Quarterly Journal of Economics May 1990: 501-526 (1990).

[17] Romer, P.: Endogenous technological change, Journal of Political Economy 98 : 71-102 (1990).

[18] Scherer, F. M.: Inter-industry technology flows and productivity growth, Review of Economics and Statistics November: 627-634 (1982).

[19] Los, B. and Verspagen, B., Technology spillovers and their impact on productivity, in Elgar Companion to Neo-Schumpeterian Economics. H. Hanusch and A. Pyka, eds., Edward Elgar, Cheltenham, 2004.

[20] David, P., Hall, B. and Toole, A.: Is public R\&D a complement or substitute for private R\&D? A review of the econometric evidence, Research Policy 29: 497-529 (2000).

[21] Bartelsman, E. J. and Doms, M.: Understanding productivity: lessons from longitudinal microdata, Journal of Economic Literature 38 (3): 569-594 (2000).

[22] Wieser, R.: Research and development productivity and spillovers: empirical evidence at the firm level, Journal of Economic Surveys 19 (4): 587-621 (2005).

[23] Griliches, Z.: The search for R\&D spillovers, Scandinavian Journal of Economics 94: S29-S47 (1992).

[24] Griliches, Z.: Issues in assessing the contribution of research and development to productivity growth, The Bell Journal of Economics 10: 92-116 (1979).

[25] Levin, R.C., Klevorick, A.A., Nelson, R.R. and Winter, S.G.: Appropriating the returns from industrial R\&D, Brookings Papers on Economic Activity 3: 783-820 (1987).

[26] Jaffe, A.B.: Technological opportunities and spillovers from R\&D: evidence from firms' patents, profits, and market value, American Economic Review 76: 9841001 (1986).

[27] Verspagen, B.: Estimating international technology spillovers using technology flow matrices, Weltwirtscaftliches Archiv 133: 226-248 (1997).

[28] Verspagen, B. and Wakelin, K.: International competitiveness and its determinants, International Review of Applied Economics 11 (2): 177-190 (1997).

[29] Ten Raa, T. and Wolff, E.N.: Engines of growth in the US economy, Structural Change and Economic Dynamics 11: 473-489 (2000).

[30] Chui, M., Levine, P., Murshed, S. M. and Pearlman, J.: North-South models of growth and trade, Journal of Economic Surveys 16 (2): 123-165 (2002). 
[31] Darity, W. and Davis, L. S.: Growth, trade and uneven development, Cambridge Journal of Economics 29: 141-170 (2005).

[32] Rivera-Batiz, L. and Romer, P.: International trade and endogenous technological change, European Economic Review 35: 971-1004 (1991).

[33] Grossman, G.M. and Helpman, E.: Innovation and Growth in the Global Economy, MIT Press, Cambridge, USA, 1991.

[34] Barba Navaretti, G. and Tarr, D. G.: International knowledge flows and economic performance: a review of the evidence, The World Bank Economic Review 14 (1): 1-15 (2000).

[35] Coe, D.T. and Helpman, E.: International R\&D spillovers, European Economic Review 39: 859-887 (1995).

[36] Coe, D.T., Helpman, E. and Hoffmaister, A.: North-South R\&D spillovers, Economic Journal 107: 134-149 (1997).

[37] Eaton, J. and Kortum, S.: Trade in ideas - Patenting and productivity in the OECD, Journal of International Economics 40: 251-278 (1996).

[38] Keller, W.: Do trade patterns and technology flows affect productivity growth?, The World Bank Economic Review 14 (1): 17-47 (2000).

[39] Gittleman, M. and Wolff, E.N.: R\&D activity and cross-country growth comparisons, Cambridge Journal of Economics 19: 189-207 (1995).

[40] Baptista, R., Clusters, innovation and growth: a survey of the literature, in The Dynamics of Industrial Clustering. International Comparisons in Computing and Biotechnology. Swann, P., Prevezer, M. and Stout, D., eds., Oxford University Press, Oxford, 1998.

[41] Feldman, M.: The new economics of innovation, spillovers and agglomeration: a review of empirical studies, Economics of Innovation and New Technology 8: 5-25 (1999).

[42] Breschi, S. and Lissoni, F.: Knowledge spillovers and local innovation systems: a critical survey, Industrial and Corporate Change 10 (4): 975-1005 (2001).

[43] Breschi, S. and Lissoni, F.: Localised knowledge spillovers vs. innovative milieux: knowledge 'tacitness' reconsidered, Papers in Regional Science 80 (3): 255 273 (2001).

[44] Krugman, P.: Geography and Trade, MIT Press, Cambridge, MA, 1991.

[45] Krugman, P.: Development, Geography and Economic Theory, MIT Press, Cambridge, MA, 1995.

[46] Krugman, P.: The Self-Organising Economy, Blackwell, Oxford, 1996. 
[47] Krugman, P. and Venables, A.: Integration, specialization and adjustment, European Economic Review 40: 959-967 (1996).

[48] Martin, R.: The new 'geographical turn' in economics: some critical reflections, Cambridge Journal of Economics 23: 65-91 (1999).

[49] Martin, R. and Sunley, P.: Paul Krugman's geographical economics and its implications for regional development theory: a critical assessment, Economic Geography 72: 259-291 (1996).

[50] Jaffe, A.B.: Real effects of academic research, American Economic Review 79: 957-970 (1989).

[51] Acs, Z. J., Audretsch, D. B. and Feldman, M. P.: Real effects of academic research: a comment, American Economic Review 82: 363-367 (1992).

[52] Acs, Z. J., Audretsch, D. B. and Feldman, M. P.: R\&D spillovers and recipient firm size, Review of Economics and Statistics 76: 336-340 (1994).

[53] Feldman, M. and Florida, R.: The geographic sources of innovation: technological infrastructure and product innovation in the United States, Annals of the Association of American Geographers 84: 210-229 (1994).

[54] Audretsch, D. B. and Feldman, M. P.: R\&D spillovers and the geography of innovation and production, American Economic Review 86: 630-640 (1996).

[55] Feldman, M. and Audretsch, D. B.: Innovation in cities: science-based diversity, specialisation and localised competition, European Economic Review 43: 409-429 (1999).

[56] Jaffe, A.B., Trajtenberg, M. and Henderson, R.: Geographic localisation of knowledge spillovers as evidenced by patent citations, Quarterly Journal of Economics 108: 577-598 (1993).

[57] Almeida, P. and Kogut, B.: The exploration of technological diversity and the geographic localization of innovation, Small Business Economics 9: 21-31 (1997).

[58] Brouwer, E., Nadvornikova, H. B. and Kleinknecht, A.: Are urban agglomerations a better breeding place for product innovations? An analysis of new product announcements, Regional Studies 33: 541-549 (1999).

[59] Kelly, M. and Hageman, A.: Marshallian externalities in innovation, Journal of Economic Growth 4: 39-54 (1999).

[60] Maurseth, P.B. and Verspagen, B.: Knowledge spillovers in Europe. A patent citation analysis, Scandinavian Journal of Economics 104: 531-545 (2002).

[61] Evangelista, R.: Knowledge and Investment. The Sources of Innovation in Industry, Edward Elgar, Cheltenham, 1999. 
[62] Nelson, R. and Winter, S.: An Evolutionary Theory of Economic Change, The Belknap Press of Harvard University Press, Cambridge, USA, 1982.

[63] Dosi, G.: Technological paradigms and technological trajectories, Research Policy 11: 147-162 (1982).

[64] Posner, M. V.: International trade and technical change, Oxford Economic Papers 13: 323-341 (1961).

[65] Soete, L.: A general test of technology gap trade theory, Weltwirtschaftliches Archiv 117: 638-660 (1981).

[66] Soete, L.: The impact of technological innovation on international trade patterns: the evidence reconsidered, Research Policy 16: 101-130 (1987).

[67] Dosi, G. and Soete, L.: Technology gaps and cost-based adjustments: some explorations on the determinants of international competitiveness, Metroeconomica, 35 (3): 197-222 (1983).

[68] Fagerberg, J.: International competitiveness, Economic Journal 98: 355-374 (1988).

[69] Fagerberg, J.: Technology and competitiveness, Oxford Review of Economic Policy 12 (3): 39-51 (1996).

[70] Dosi, G. Pavitt, K. and Soete, L.: The Economics of Technical Change and International Trade, Harvester Wheatsheaf, London, 1990.

[71] Amendola, G., Dosi, G. and Papagni, E.: The dynamics of international competitiveness, Weltwirtschaftliches Archiv 129 (3): 451-471 (1993).

[72] Magnier, A. and Toujas-Bernate, J.: Technology and trade: empirical evidences for the major five industrialized countries, Weltwirtschaftliches Archiv 130 (3): 494520 (1994).

[73] Amable, B. and Verspagen, B.: The role of technology in market shares dynamics, Applied Economics 27: 197-204 (1995).

[74] Padoan, P.C.: Trade, knowledge accumulation and diffusion: a sectoral perspective, Structural Change and Economic Dynamics 9: 349-372 (1998).

[75] Montobbio, F.: Sectoral patterns of technological activity and export market share dynamics, Cambridge Journal of Economics 27: 523-545 (2003).

[76] Gerschenkron, A.: Economic Backwardness in Historical Perspective, Harvard University Press, Cambridge, 1962.

[77] Abramovitz, M.: Catching-up, forging ahead and falling behind, Journal of Economic History 46: 385-406 (1986). 
[78] Abramovitz, M., The origins of the postwar catch-up and convergence boom, in The Dynamics of Technology, Trade and Growth. Fagerberg, J., Verspagen, B. and Von Tunzelmann, N., eds., Edward Elgar, Aldershot, 1994.

[79] Cornwall, J.: Modern Capitalism, its Growth and Transformations, Martin Robertson, London, 1977.

[80] Verspagen, B.: A new empirical approach to catching up or falling behind, Structural Change and Economic Dynamics 2: 359-380 (1991).

[81] Amable, B.: Catch-up and convergence in a model of cumulative growth, International Review of Applied Economics 7: 1-25 (1993).

[82] Fagerberg, J. and Verspagen, B.: Technology-gaps, innovation-diffusion and transformations: an evolutionary interpretation, Research Policy 31: 12911304 (2002).

[83] Castellacci, F.: A neo-Schumpeterian approach to why growth rates differ, Revue Economique 55 (6): 1145-1169 (2004).

[84] Porter, M.: The Competitive Advantage of Nations, Macmillan, London, 1990.

[85] Lundvall, B.A.: National Systems of Innovation: Towards a Theory of Innovation and Interactive Learning, Pinter Publishers, London, 1992.

[86] Malerba, F., Sectoral systems: how and why innovation differs across sectors, in The Oxford Handbook of Innovation. J. Fagerberg, D. C. Mowery and R. R. Nelson, eds., Oxford University Press, Oxford, 2005.

[87] Pavitt, K.: Sectoral patterns of technical change: towards a taxonomy and a theory, Research Policy 13: 343-373 (1984).

[88] Marsili, O., Verspagen, B.: Technology and the dynamics of industrial structure: an empirical mapping of Dutch manufacturing, Industrial and Corporate Change 11 (4): 791-815 (2002).

[89] Castellacci, F.: Technological regimes and sectoral differences in productivity growth, Industrial and Corporate Change, in press (2007).

[90] Pianta, M. and Vaona, A.: Innovation and productivity in European industries, Economics of Innovation and New Technologies, in press (2007).

[91] Fagerberg, J.: User-producer interaction, learning and comparative advantage, Cambridge Journal of Economics 19: 243-256 (1995).

[92] Fagerberg, J. and Verspagen, B., Productivity, R\&D spillovers and trade, in Productivity, Technology and Economic Growth. Van Ark, B., Kuipers, S.K. and Kuper, G.H., eds., Kluwer Academic Publishers, Dordrecht, 2000. 
[93] Laursen, K. and Meliciani, V.: The relative importance of international vis-à-vis national technological spillovers for market share dynamics, Industrial and Corporate Change 11 (4): 875-894 (2002).

[94] Laursen, K. and Drejer, I.: Do inter-sectoral linkages matter for international export specialisation?, Economics of Innovation and New Technology 8: 311-330 (1999).

[95] Laursen, K. and Meliciani, V.: The importance of technology based intersectoral linkages for market share dynamics, Weltwirtscaftliches Archiv 136 (4) (2000).

[96] Winter, S. G.: Schumpeterian Competition in Alternative Technological Regimes, Journal of Economic Behavior and Organization 5: 137-158 (1984).

[97] Cohen, W.M. and Levin, R., Empirical studies of innovation and market structure, in Handbook of Industrial Organization, Volume II. R. Schmalensee and R.D. Willig, eds., North Holland, 1989.

[98] Breschi, S. and F. Malerba, Sectoral innovation systems: technological regimes, Schumpeterian dynamics, and spatial boundaries, in Systems of Innovation:

Technologies, Institutions and Organisations. C. Edquist, ed., Pinter, London and Washington, 1997.

[99] Marsili, O.: The Anatomy and Evolution of Industries: Technological Change and Industrial Dynamics, Edward Elgar, Cheltenham, UK, 2001.

[100] Malerba, F. and Orsenigo, L.: Schumpeterian patterns of innovation, Cambridge Journal of Economics 19: 47-65 (1995).

[101] Malerba, F. and Orsenigo, L.: Schumpeterian patterns of innovation are technology-specific, Research Policy 25: 451-478 (1996).

[102] Breschi, S., Malerba, F. and Orsenigo, L.: Technological regimes and Schumpeterian patterns of innovation, Economic Journal 110: 388-410 (2000).

[103] Schumpeter, J.: Capitalism, Socialism and Democracy, Harper, New York, 1943.

[104] Malerba, F. and Montobbio, F.: Exploring factors affecting international technological specialization: the role of knowledge flows and the structure of innovative activity, Journal of Evolutionary Economics 13: 411-434 (2003).

[105] Laursen, K.: The impact of technological opportunity on the dynamics of trade performance, Structural Change and Economic Dynamics 10: 341-357 (1999).

[106] Lee, K. and Lim, C.: Technological regimes, catching-up and leapfrogging: findings from the Korean industries, Research Policy 30: 459-483 (2001). 
[107] Hekkert, M.P., Suurs, R.A.A., Negro, S.O., Kuhlmann, S. and Smits, R.E.H.M.: Functions of innovation systems: a new approach for analysing technological change, Technological Forecasting and Social Change 74 (4): 413-432 (2006).

[108] Mowery, D. and Nelson, R.: The Sources of Industrial Leadership, Cambridge University Press, Cambridge, 1999.

[109] Murmann, J. P. and Homburg, E.: Comparing evolutionary dynamics across different national settings: the case of the synthetic dye industry, 1857-1914, Journal of Evolutionary Economics 11: 177-205 (2001).

[110] Dalum, B., Laursen, K. and Verspagen, B.: Does specialization matter for growth?, Industrial and Corporate Change 8: 267-288 (1999).

[111] Amable, B.: International specialisation and growth, Structural Change and Economic Dynamics 11: 413-431 (2000).

[112] Fagerberg, J.: Technological progress, structural change and productivity growth: a comparative study, Structural Change and Economic Dynamics 11: 393$411(2000)$.

[113] Landesmann, M. and Stehrer, R.: Convergence patterns and switchovers in comparative advantage, Structural Change and Economic Dynamics 12: 399-423 (2001).

[114] Montobbio, F.: An evolutionary model of industrial growth and structural change, Structural Change and Economic Dynamics 13: 387-414 (2002).

[115] Carree, M.A.: Technological progress, structural change and productivity growth: a comment, Structural Change and Economic Dynamics 14: 109-115 (2003).

[116] Peneder, M.: Industrial structure and aggregate growth, Structural Change and Economic Dynamics 14: 427-488 (2003).

[117] Archibugi, D. and Pianta, M.: Aggregate convergence and sectoral specialization in innovation, Journal of Evolutionary Economics 4: 17-33 (1994).

[118] Dalum, B., Laursen, K. and Villumsen, B.: Structural change in OECD export specialisation patterns: de-specialisation and 'stickiness', International Review of Applied Economics 12 (3): 423-442 (1998).

[119] Begg, I., Dalum, B., Guerrieri, P., and Pianta, M., The impact of specialization in Europe, in The Economic Challenge for Europe - Adapting to Innovation Based Growth. J. Fagerberg, P. Guerrieri and B. Verspagen, eds., Edward Elgar, Cheltenham, 1999.

[120] Laursen, K.: Do export and technological specialisation patterns co-evolve in terms of convergence or divergence? Evidence from 19 OECD countries 1971-1999, Journal of Evolutionary Economics 10: 415-436 (2000). 
[121] Cefis, E. and Orsenigo, L.: The persistence of innovative activities: a crosscountries and cross-sectors comparative analysis, Research Policy 30: 1139-1158 (2001).

[122] Fai, F. and von Tunzelmann, N.: Industry-specific competencies and converging technological systems: evidence from patents, Structural Change and Economic Dynamics 12: 141-170 (2001).

[123] Laursen, K. and Salter, A.: The fruits of intellectual production: economic and scientific specialisation among OECD countries, Cambridge Journal of Economics 29: 289-308 (2005).

[124] Narula, R.: Innovation systems and 'inertia' in R\&D location: Norwegian firms and the role of systemic lock-in, Research Policy 31 (5): 795-816 (2002).

[125] Lundvall, B. A. and S. Borrás, Science, technology and innovation policy, in The Oxford Handbook of Innovatio. J. Fagerberg, D. C. Mowery and R. R. Nelson, eds., Oxford University Press, Oxford, 2005.

[126] Mowery, D. and Sampat, B., Universities in national innovation systems, in The Oxford Handbook of Innovation. J. Fagerberg, D. C. Mowery and R. R. Nelson, eds., Oxford University Press, Oxford, 2005.

[127] Powell, W. and Grodal, S., Networks of innovators, in The Oxford Handbook of Innovation. J. Fagerberg, D. C. Mowery and R. R. Nelson, eds., Oxford University Press, Oxford, 2005.

[128] Breschi, S. and F. Malerba: The geography of innovation and economic clustering: some introductory note, Industrial and Corporate Change 10 (4): 817-833 (2001).

[129] Narula, R. and Zanfei, A., Globalisation of innovation: the role of multinational enterprises, in The Oxford Handbook of Innovation. J. Fagerberg, D. C. Mowery, and R. R. Nelson, eds., Oxford University Press, Oxford, 2005.

[130] Gertler, M., Wolfe, D. and Garkut, D.: No place like home? The embeddedness of innovation in a regional economy, Review of International Political Economy 7 (4): 688-718 (2000).

[131] Cooke, P.: Regional innovation systems, clusters and the knowledge economy, Industrial and Corporate Change 10 (4): 945-973 (2001).

[132] Todtling, F. and Trippl, M.: One size fits all? Towards a differentiated regional innovation policy approach, Research Policy 34: 1203-1219 (2005).

[133] Asheim, B and Gertler, M., The geography of innovation: regional innovation systems, in, The Oxford Handbook of Innovation. J. Fagerberg, D. C. Mowery and R. R. Nelson, eds., Oxford University Press, Oxford, 2005. 
[134] Asheim, B and Coenen, L.: Knowledge bases and regional innovation systems: comparing Nordic clusters, Research Policy 34: 1173-1190 (2005).

[135] Neven, D. and Gouyette, C.: Regional Convergence in the European Community, Journal of Common Market Studies 33: 47-65 (1995).

[136] Fagerberg, J. and Verspagen, B.: Heading for Divergence? Regional Growth in Europe Reconsidered, Journal of Common Market Studies 34: 431448 (1996).

[137] Fagerberg, J., B. Verspagen and Caniëls, M.: Technology, Growth and Unemployment across European Regions, Regional Studies 31: 457-66 (1997).

[138] Cappelen, A., J. Fagerberg and B. Verspagen, Lack of Regional Convergence, in The Economic Challenge for Europe. Adapting to Innovation Based Growth. J. Fagerberg, P. Guerrieri and B. Verspagen, eds., Edward Elgar, Aldershot, UK, 1999.

[139] Cappelen A., Castellacci, F., Fagerberg J. and Verspagen, B.: The impact of regional support on growth and convergence in the European Union, Journal of Common Market Studies 41 (4): 621-644 (2003).

[140] Giannetti, M.: The effects of integration on regional disparities: convergence, divergence or both?, European Economic Review 46: 539-567 (2002).

[141] Gardiner, B., Martin, R. and Tyler, P.: Competitiveness, productivity and economic growth across the European regions, Regional Studies 38 (9): 1045-1067 (2004).

[142] Mora, T., Vaya, E. and Surinach, J.: Specialisation and growth: the detection of European convergence clubs, Economic Letters 86: 181-185 (2005).

[143] Baumol, W. J.: Pareto optimal sizes of innovation spillovers, Economic Research Report 97-42, C.V. Starr Center for Applied Economics, New York University (1997).

[144] Baumol, W. J.: The Free-Market Innovation Machine: Analyzing the Growth Miracle of Capitalism, Princeton University Press, Princeton, New Jersey, 2002.

[145] Lipsey, R. and Carlaw, K.: Technology policies in neo-classical and structuralist-evolutionary models, STI Review 22: 31-73 (1998).

[146] Nyholm, J., Normann, L., Frelle-Petersen, C., Riis, M. and Torstensen, P., Innovation policy in the knowledge-based economy: can theory guide policy making?, in The Globalizing Learning Economy. D. Archibugi and B.Å. Lundvall, eds., Oxford University Press, Oxford, 2002.

[147] Knight, F. H.: Risk, Uncertainty and Profit, Houghton Mifflin, Boston, MA, 1921. 
[148] Metcalfe, S. and Georghiou, L.: Equilibrium and evolutionary foundations of technology policy, STI Review 22: 75-100 (1998).

[149] Conceição, P., Heitor, M.V. and Veloso, F.: Infrastructures, incentives, and institutions: fostering distributed knowledge bases for the learning society, Technological Forecasting and Social Change 70 (7): 583-617 (2003).

[150] Dosi, G., Marengo, L. and Pasquali, C.: How much should society fuel the greed of innovators? On the relations between appropriability, opportunities and rates of innovation, Research Policy 35 (8): 1110-1121 (2006).

[151] Von Tunzelmann, N. and Acha, V., Innovation in 'low-tech' industries, in The Oxford Handbook of Innovation. Fagerberg, J., Mowery, D.C., and Nelson, R.R., eds., Oxford University Press, Oxford, 2005.

[152] Malerba, F.: Economia dell'Innovazione, Carocci, Roma, 2000.

[153] Arranz, N. and de Arroyabe, J.C.F.: Joint R\&D projects: experiences in the context of European technology policies, Technological Forecasting and Social Change 73 (7): 860-885 (2006).

[154] Kuhlmann, S. and Edler, J.: Scenarios of technology and innovation policies in Europe: investigating future governance, Technological Forecasting and Social Change 70 (7): 619-637 (2003).

Fulvio Castellacci is Head of Department and Senior Research Fellow at the Department of International Economics, Norwegian Institute of International Affairs (NUPI). He holds a PhD in Innovation Studies from the University of Oslo and a $\mathrm{PhD}$ in Economics from the University of Rome La Sapienza. His research interests relate to the field of innovation, growth and development. 
Figure 1: Innovation and the competitiveness of industries: an evolutionary interpretation
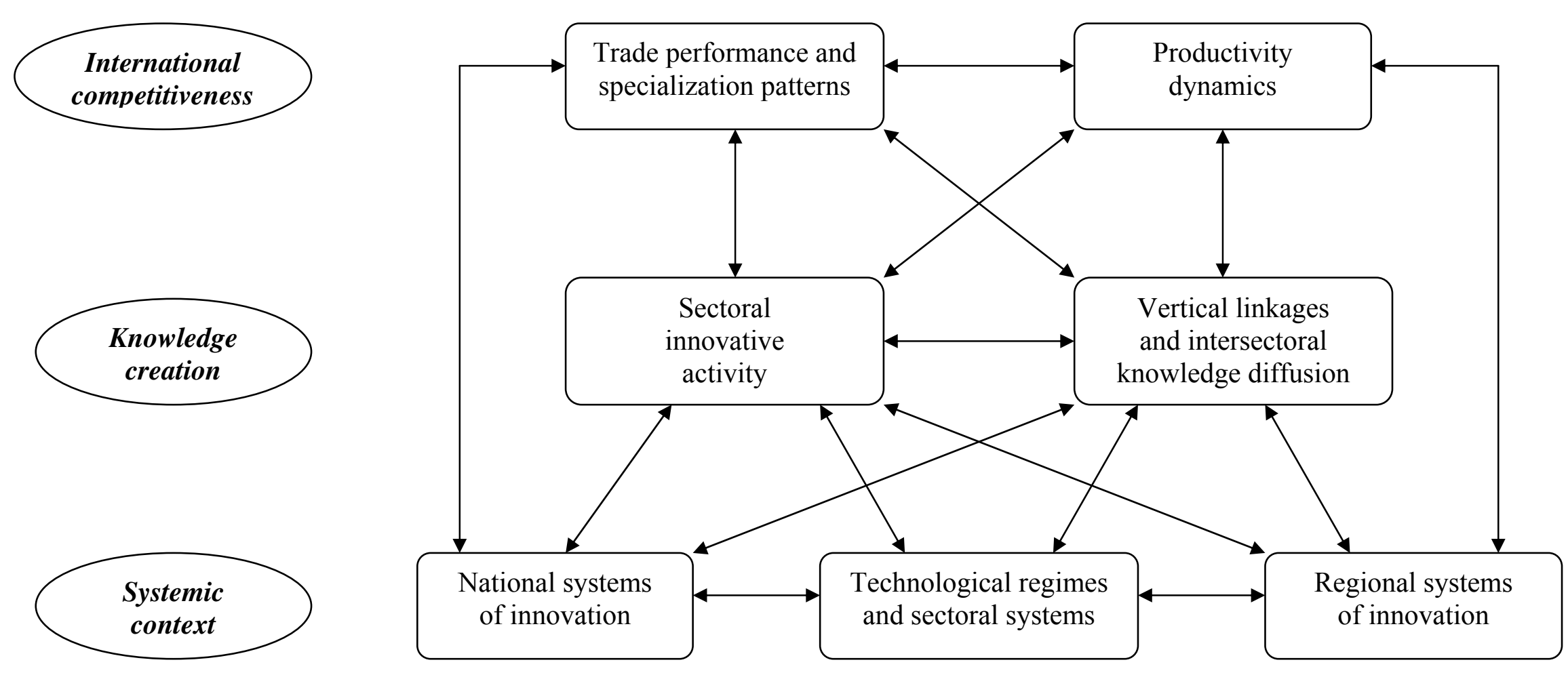
Table 1: Policy foundations and objectives: comparing the mainstream and the evolutionary approaches

\begin{tabular}{|c|c|c|}
\hline & Mainstream R\&D spillovers approach & Evolutionary economics approach \\
\hline $\begin{array}{l}\text { Theoretical } \\
\text { foundations }\end{array}$ & $\begin{array}{c}\text { Focus on R\&D activities } \\
\text { Linear model of innovation } \\
\text { Equilibrium context and Pareto optimality } \\
\text { Private R\&D expenditures are sub-optimal: the market failure approach } \\
\text { The policy-maker is a rational and well-informed social planner } \\
\text { A computable risk economic environment } \\
\text { Methodological individualism: the context is not crucial } \\
\text { One-size-fits-all models and generic policies }\end{array}$ & $\begin{array}{l}\text { Focus on sector-specific technological and learning capabilities } \\
\text { Systemic model of innovation } \\
\text { Disequilibrium framework and complex evolving system } \\
\text { An optimal level cannot be defined: the system failure approach } \\
\text { The policy-maker has bounded rationality and limited information } \\
\text { A radically uncertain economic environment } \\
\text { Non-reductionism: the context is crucial } \\
\text { Context-dependent explanations and specific policies }\end{array}$ \\
\hline $\begin{array}{c}\text { Policy } \\
\text { rationale }\end{array}$ & $\begin{array}{l}\text { Correct the failures in the knowledge market } \\
\text { by designing an appropriate set of incentives and } \\
\text { resources to stimulate private } R \& D \text { activities }\end{array}$ & $\begin{array}{l}\text { Strengthen the learning capabilities of the components } \\
\text { of the system, and the interactions among them, by means of } \\
\text { an appropriate set of sector- and context-specific measures }\end{array}$ \\
\hline $\begin{array}{c}\text { Policy } \\
\text { objectives }\end{array}$ & $\begin{array}{l}\text { Increase the size of the domestic R\&D sector } \\
\text { Support trade specialization patterns and comparative advantages } \\
\text { Strengthen regional specialization patterns and advanced clusters }\end{array}$ & $\begin{array}{l}\text { Target sector-specific technological regimes and trajectories } \\
\text { Strengthen vertical linkages and competitive advantages } \\
\text { Coordinate sectoral, national and regional policies }\end{array}$ \\
\hline
\end{tabular}

